\title{
Heretical Networks between East and West: The Case of the Fraticelli
}

\section{NICKIPHOROS I. TSOUGARAKIS}

\begin{abstract}
This article explores the links between the Franciscan heresy of the Fraticelli and the Latin territories of Greece, between the thirteenth and fifteenth centuries. It argues that the early involvement of Franciscan dissidents, like Angelo Clareno, with the lands of Latin Romania played an important role in the development of the Franciscan movement of dissent, on the one hand by allowing its enemies to associate them with the disobedient Greek Church and on the other by establishing safe havens where the dissidents were relatively safe from the persecution of the Inquisition and whence they were also able to send missionaries back to Italy to revive the movement there. In doing so, the article reviews all the known information about Fraticelli communities in Greece, and discovers two hitherto unknown references, proving that the sect continued to exist in Greece during the Ottoman period, thus outlasting the Fraticelli communities of Italy.
\end{abstract}

Keywords: Fraticelli; Franciscan Spirituals; Angelo Clareno; heresy; Latin Romania; Venetian Crete. 


\section{Heretical Networks between East and West: The Case of the Fraticelli}

The flow of heretical ideas between Byzantium and the West is well-documented ever since the early Christian centuries and the Arian controversy. The renewed threat of popular heresy in the High Middle Ages may also have been influenced by the East, though it was equally fuelled by developments in western thought. The extent to which Catharism may have originated from Bulgaria and the Byzantine Empire has been vigorously challenged in recent decades and the debate rages on today, but the 'traditionalist' claim that eastern missionaries had undertaken the active proselytising and organisation of Cathar churches in the West has never been definitively discredited. ${ }^{1}$ Moreover, Bernard Hamilton and others have argued that the first Cathar church was not founded in the West, nor for that matter in Bogomil Bulgaria, but was started by Crusaders of the First Crusade inside Constantinople. The same scholars have done much work illustrating the dissemination of heretical texts from East to West. $^{2}$

\footnotetext{
${ }^{1}$ For a thorough review of the state of the question see the recent and thought provoking Antonio Sennis, ed., Cathars in Question (York: York Medieval Press, 2016), in which the traditionalists appear to have the best of the debate. See also, Bernard Hamilton, 'Bogomil Influences on Western Heresy', in Heresy and the Persecuting Society: Essays on the Work of R.I. Moore, ed. Michael Frassetto (Leiden and Boston: Brill, 2006), 93-114. The revisionist views are most clearly represented in the numerous studies of Mark Pegg, included and cited in the above-mentioned volumes.

${ }^{2}$ Bernard Hamilton, 'Wisdom from the East: the Reception by the Cathars of Eastern Dualist Texts', in Heresy and Literacy, 1000-1530, ed. Peter Biller and Anne Hudson (Cambridge: Cambridge University Press, 1994), 44-5 discusses the evidence for a Constantinopolitan provenance of Catharism.
} 
This process of cross-fertilization between East and West manifested itself also in the case of the movement of Franciscan dissent and the heresy that sprang from it in the fourteenth century, the Fraticelli. ${ }^{3}$ Though the presence of numerous Fraticelli heretics in the Latin states of the former Byzantine Empire has long been noted, the consequences of the movement's history in the East have not been fully explored. This paper attempts to show that the movement's early involvement in the East influenced the way it was perceived by its enemies in the West, but also played an important role both in its subsequent history and in the self-perception of some of its members.

The term 'Franciscan dissent' refers to the major controversy that erupted, firstly within the Franciscan order itself and subsequently within the Latin Church as a whole, concerning the absolute poverty of Christ and the apostles and the need to imitate this example as per the wishes of St Francis. ${ }^{4}$ To give a brief outline of the controversy: different schools of thought appeared within the order already during Francis's lifetime (1181/2-1226),

\footnotetext{
${ }^{3}$ The most thorough modern treatment of the Fraticelli is in Duncan Nimmo, Reform and Division in the Medieval Franciscan Order: from Saint Francis to the Foundation of the Capuchins (Rome: Istituto Storico dei Cappuccini, 1995), 241-352. Useful overviews, accompanied by fairly exhaustive bibliographies for the earlier studies up to the mid-twentieth century can also be found in Clément Schmitt, 'Fraticelles', in Dictionnaire de spiritualité ascétique et mystique, doctrine et histoire, ed. Marcel Viller et al. (Paris: Beauchesne, 1937-95), 1167-87; and in Schmitt, 'Fraticelles', in Dictionnaire d'histoire et de géographie ecclésiastiques, ed. Alfred Baudrillart et al. (Paris: Letouzey et Ané, 1912-), 1063-1108. See also, Decima L. Douie, The Nature and Effect of the Heresy of the Fraticelli (Manchester: Manchester University Press, 1932).

${ }^{4}$ See David Burr, The Spiritual Franciscans: From Protest to Persecution in the Century after Saint Francis (University Park Pennsylvania: Pennsylvania University Press, 2001); and Nimmo, Reform and Division.
} 
among the modernisers, who saw the need to relax the more extreme rules on poverty and the rigorists, who (like Francis) insisted on the strictest upholding of poverty. In the decades following the death of Francis, the modernisers (also called the Conventuals), with the support of the papacy, won control of the order and began persecuting the rigorists, now referred to as the Spirituals. Though the Spirituals were not officially classed as heretics, they were sometimes treated as such, since they were perceived as intransigent zealots who refused to obey their superiors. For their part, the zealots felt that the order was drifting away from the vision of its founder, and were determined to persevere in absolute poverty, imitating the example of Francis and ultimately -as they believed-Christ. One of the main issues of contention was the adherence to St Francis's Testament, which the Spirituals saw as a divinely inspired document (equal in standing to the Bible) which ought to be followed by all members of the order despite the fact the papacy had declared it non-binding. The debate entered a new phase under the papacy of John XXII (1316-34). ${ }^{5}$ Unlike some of his predecessors, e.g. Celestine V (1294) and Clement V (1305-14), who had attempted to resolve the issue by forcing a compromise between the two camps, John tried to end the controversy by suppressing the Spirituals. The rulings of Quorumdam exigit and Sancta Romana cleared the way for the execution of dissident friars, four of whom were burnt at Marseilles on 7 May 1318, becoming martyrs for the movement. But in trying to remove the theological basis of the Spirituals' beliefs, John XXII went further, questioning whether Christ and the Apostles had been absolutely poor. Eventually, following on from Quorumdam exigit and Sancta Romana, John XXII published a series of rulings that declared it heretical to assert that Christ and the apostles had held no property either personally or communally and also did away with the legal figment that allowed the Franciscans to make free use of

\footnotetext{
${ }^{5}$ Nimmo, Reform and Division, 134-8 and 190-3; and Burr, The Spiritual Franciscans, 179-212.
} 
property, without ever owning it. ${ }^{6}$ This was a step too far even for many of the Conventual Franciscans who had collaborated in the suppression of the Spirituals, for the denial of Christ's poverty challenged the whole basis of the Franciscan lifestyle. In this debate, the mainstream friars found themselves in the paradoxical position of defending their order by falling back on arguments that had been championed by the persecuted Spirituals.

Most of the Franciscan order had no choice but to accept these rulings, but some, including the former General Minister Michael of Cesena (c.1270-1342), denounced them. These rebel Franciscans, who were the heirs of the Spirituals - even if they were not previously part of that movement-, were now bona fide heretics, since they explicitly challenged the doctrines of the Church and became known as the Fraticelli. Though they lacked a clear organisation, they were perceived as belonging to two different groups. The

\footnotetext{
${ }^{6}$ The decree Quorumdam exigit (7 October 1317) ruled that Franciscan priors would decide what was considered poor clothing and what amount of food provision was acceptable, thus giving Conventual priors leeway to enforce their own interpretation of poverty. Sancta Romana (30 December 1317) condemned all the separatist friars. Quia nonnumquam (26 March 1322) overturned the previous decree of Nicholas III (Exiit qui seminat) by which any glossing of the Rule of St Francis had been forbidden. Ad conditorem (8 December 1322) overturned the clause of Exiit qui seminat which allowed the Franciscans to make use of goods whose ownership remained technically in the hands of the Holy See, thereby forcing the order to accept temporal ownership of property. Finally, Cum inter nonnullos (12 November 1323) decreed it heretical to assert that Christ and the apostles had held no property either individually or communally. The first four of these decrees are published in Conrad Eubel, ed., Bullarium Franciscanum, 7 vols. (Rome: Typis Sacrae Congregationis de Propaganda Fide, 1898), 5:128-30, 134-5, 224-5, 233-4. The final one is published in Jacqueline Tarrant, ed., Extravagantes Iohannis XXII (Vatican: Biblioteca Apostolica Vaticana, 1983), 255-7. See also the discussion of these documents in Burr, The Spiritual Franciscans, 196-204.
} 
first, more directly related to the Spirituals were known as the Fraticelli de paupere vita and, as their name denotes, were primarily interested in following the strict and poor apostolic lifestyle as they interpreted it. Many of them were members of the laity or Franciscan tertiaries rather than full members of the order, and are identified in the documents as beguini (in France) and bizochi (in Italy). The second group, the Fraticelli de opinione, coalesced around Michael of Cesena, and was the intellectual branch of the sect, probably comprised mainly of Franciscan friars. The Church brought the full power of the Inquisition against the Fraticelli, which led to a hardening of attitudes: the sectarians claimed that through the bulls of John XXII, the entire Catholic Church had fallen into heresy, and were alleged to have set up their own ecclesiastical hierarchy and eventually to elect their own 'pope'. ${ }^{7}$ The last record of the heresy comes from an inquisitorial trial held in Rome in 1466-67 after which time the heresy supposedly disappears. ${ }^{8}$

The involvement of Franciscan dissidents with Greece starts already with the Spiritual movement. At the close of the thirteenth century (c.1295) a group of Anconitan Spirituals under the leadership of Liberato and of Angelo Clareno (1247/8-1337), who would become one of the protagonists of the movement, fleeing the persecution of the Conventuals and the new hostile pope (Boniface VIII), travelled to Frankish Greece and settled on a little island,

\footnotetext{
${ }^{7}$ The charge of heresy was levelled against John XXII primarily on the basis that he had gone against the Rule of St Francis and thus, as the Spirituals saw it, against the Gospels.

${ }^{8}$ The record of the trial is published in Franz Ehrle, ed., 'Die Spiritualen, ihr Verhältniss zum Franziskanerorden und zu den Fraticellen: Das Verhältniss der Spiritualen zu den Fraticellen; Der Process gegen die beim Portiunculafest in Assisi 1466', Archiv für Litteratur und Kirchen geschichte des Mittelalters 4 (1888): 110-34. Nimmo, Reform and Division, 241, affirms that the heresy disappears after 1466-67.
} 
where they lived according to the apostolic lifestyle and gained a reputation for holiness. ${ }^{9}$ Even there, however, they were persecuted by the Franciscans of Greece (possibly those of Negroponte), who initially and unsuccessfully accused them of Catharism, before finally convincing Pope Boniface VIII (1294-1303) to investigate them, thus forcing them to go on the run in Thessaly, where they found refuge in an unnamed Greek monastery. There, Angelo was graced by a miracle through which he learned perfectly the Greek language. Eventually they returned to Italy where they were once again persecuted. Clareno himself avoided the Inquisition, but he was forced to appear at the papal court of Avignon (1317-18) where his

\footnotetext{
${ }^{9}$ For Angelo Clareno (real name Peter of Fossombrone) see in particular Lydia von Auw, Angelo Clareno et les Spirituels Italiens (Rome: Edizioni di storia e letteratura, 1979), and also his own writings: Angelo Clareno, A Chronicle or History of the Seven Tribulations of the Order of Brothers Minor, ed. and trans. David Burr and E. Randolph Daniel (St Bonaventure, New York: Franciscan Institute Publications, 2005); Angelo Clareno, Historia Septem Tribulationum Ordinis Minorum, ed. Orietta Rossini (Rome: Istituto storico italiano per il Medio Evo, 1999); and Angelo Clareno, Epistole: Opera I, ed. Lydia von Auw (Rome: Istituto storico italiano per il Medio Evo, 1980). The island on which the Franciscan fugitives settled was identified by Franz Ehrle as Trixonia (more correctly, Trizonia) in the Gulf of Corinth, and this identification was followed also by von Auw. The identification is based on Clareno's assertion in the Historia (496) that the island was in the domains of Lord Thomas de Sola, which is taken to mean Thomas III d'Autremencourt, Lord of Salona. The proposed identification is plausible, even though many other similar islands could be proposed on the basis of this evidence. No material evidence of Franciscan habitation have survived on the tiny island of Trizonia. See Franz Ehrle, ed., 'Die "historia septem tribulationum ordinis minorum” des fr. Angelus de Clarino. (Die dritte, vierte und fünfte tribulatio)', Archiv für Litteratur und Kirchen geschichte des Mittelalters 2 (1886): 313-17.
} 
Orthodoxy was investigated by John XXII. ${ }^{10}$ It was during this investigation that the first effect of the Greek connection emerges: one of the accusations that Angelo had to face was that he held the Greek Church in higher regard than the Latin one. ${ }^{11}$ Angelo strenuously denied this, but it is certain that he had developed a great respect for the eastern tradition. He had translated John Climacus's work and the Rule of St Basil into Latin and, as von Auw has shown, his other writings frequently and expertly cited the Greek fathers. ${ }^{12}$ Moreover, the fact that he had stayed in a Greek monastery along with a multitude of his followers (as many as 80 according to one report) is highly unusual for that period. ${ }^{13}$ Though Angelo's orthodoxy was proven, the accusations of empathy with the Greek Church must have made an impression, for, as we shall see, they were later levelled again, against the proponents of apostolic poverty.

${ }^{10}$ For an overview of Angelo's career after his return to Italy and his influence on the movement, see Burr, The Spiritual Franciscans, 279-304.

${ }^{11}$ See Angelo’s 'Epistula Excusatoria’, published in Clareno, Epistole, pp. 236-53, here p. 240.

${ }^{12}$ von Auw, Angelo Clareno, 64-6.

${ }^{13}$ See Felice Tocco, Studii Francescani (Naples: Francesco Perrella, 1909), 293. The prolonged cohabitation of Greek and Latin religious in the same monastery seems to have been exceptional in Latin Romania. Certainly, there exist examples of Greek monasteries, like that of Theotokos Evergetis in Constantinople, which were placed under the stewardship of Latin monks, but continued to be inhabited by Greek monks, but this did not involve the cohabitation of the two communities. Conversely there are also examples of Greek monks refusing to show obedience to the papacy and choosing to abandon their house instead, as seems to have been the case with the monastery of Rufiniano. See William O. Duba and Christopher D. Schabel, eds., Bullarium Hellenicum: Pope Honorius III's Letters to Frankish Greece and Constantinople (1216-1227) (Turnhout: Brepols, 2015), pp. 72-4. 
It is even more interesting to note that the authority of the Greek Church was, shortly afterwards, brought to bear on the Franciscan poverty debate, a debate that was entirely the product of western thought and western religious traditions. What is more, on this occasion, the authority of the Greek Church was invoked by one of Angelo Clareno's most ardent denouncers, Jerome Catalano. ${ }^{14}$ As mentioned above, when John XXII attacked the principle of the absolute poverty of Christ, the mainstream Franciscans found themselves defending some of the positions that the Spirituals had already fought for. Thus it was with Jerome Catalano. Jerome was one of the brightest stars of the Franciscans in the East, rising to the rank of Provincial Minister and bishop of Caffa on the Black Sea. Before all this, however, he had briefly been part of Angelo's group in Greece, though Angelo later claimed that Jerome had infiltrated his community as a spy for the Conventuals. ${ }^{15}$ He was also the author of a letter to John XXII denouncing Angelo, which was used against Angelo Clareno in the papal court. ${ }^{16}$ Another document, however, claims that in 1322, when debates were held in John XXII's court over the poverty of Christ, Jerome Catalano took the floor and addressed the pope saying:

All the Orientals and especially the Greeks, knowledgeable of the doctrines of the saintly fathers, affirm and hold it almost as an

\footnotetext{
${ }^{14}$ For the career of this important Franciscan missionary see Girolamo Golubovich, ed., Biblioteca bio-bibliografica della Terra Santa e dell' Oriente Francescano, 5 vols. (Florence: Quaracchi 190627), 3:38-58, and José Maria Pou y Martí, Visionarios, Beguinos y Fraticelos Catalanes (Alicante: Instituto de Cultura 'Juan Gil-Albert', 1996), 348-71.

${ }^{15}$ See Angelo's 'Epistula Excusatoria', published in Clareno, Epistole, pp. 236-53, here pp. 247-8.

${ }^{16}$ Franz Ehrle, ed., 'Zur Vorgeschichte des Concils von Vienne: Des Ordensprocurators Raymund von Fronsac; Actensammlung zur Geschichte der Spiritualen', Archiv für Litteratur und Kirchen geschichte des Mittelalters 3 (1887): 1-32, here 13.
} 
article of faith that Christ and the blessed Virgin and the apostles, when they followed Christ preaching, observed such great and high poverty that they held no property or dominion over anything, neither personally nor communally; and in fact it is very insulting to us that those who are outside of the Holy Church understand and preach about the poverty of Christ and the apostles better and more perfectly than the Church of Christ does; to such a degree that if we were to preach and say differently, that is the opposite, they would stone us. ${ }^{17}$

It would thus appear, if the author of this account is to be trusted, that the Franciscans who went to Greece, whether orthodox like Jerome, or disobedient like Clareno, sought affirmation for the doctrine of apostolic poverty in Greek spirituality.

17 'Tutti gli orientali, e spezialemente gli greci, informati della dottrina delgli antichi santi dottori, affermano, e per articolo di fede quasi ànno, che Cristo e la beata vergine e gli appostoli, dappoi ch'egli seguitarono Cristo predicante, oservarono sì grande povertate e sì altissima, che nonn' ebbero proprietade, nè signoria d'alcuna cosa, nè ispeziale, nè in commune; e impertanto molto è a noi vituperoso, che, quelgli che sono fuori della santa chiesa, sentono e predicano più altamente e più perfettamente della povertà di Cristo e delgli suoi appostoli, che la chiesa di Cristo; imperciò che se noi predicassimo, o dicessimo l'opposito, cioè il contrario, essi ci lapiderebbono.' Francesco Zambrini, ed., Storia di Fra Michele Minorita, come fu arso in Firenze nel 1389, con documenti risguardanti i Fraticelli della povera vita (Bologna: G. Romagnoli, 1864), 72. The document in question appears in the appendix under the title 'Cronica della Quistione nella Corte di Papa Giovanni XXII a Vignone, circa la povertà di Cristo', 59-87. 
Not long afterwards, in 1332-34 a full-blown case of Fraticellism was reported in Armenia. ${ }^{18}$ On this occasion, some Genoese merchants reported to the Dominican bishop of Tabris that some of the city's friars openly held and preached heretical views during their Sunday sermons. Without making any arrests, the bishop conducted secret investigations, interviewed witnesses and sent his findings to the pope. The bishop's report showed that there existed a hard core of Fraticelli friars in the city, who held the usual views about poverty and the illegitimacy of the pope. One of the Fraticelli friars, Raynerius of Florence, is reported to have said by way of prophesy that the Franciscan order would be divided into three parts, and only one of these would be saved, the part that is, that would go to the East, and it was for this reason that the friars had come to those Eastern parts. ${ }^{19}$ Apocalyptic ideas were always prominent within the literate strata of the sect, partly under the influence of Joachim of Fiore (c.1132-1202), but especially as mediated by Peter of John Olivi (1247/81298), who was seen as a prophet and, sometimes as an apocalyptic figure in his own right, by some of the dissidents. ${ }^{20}$ In fact, the friars in question were undoubtedly familiar with

\footnotetext{
${ }^{18}$ Golubovich, Biblioteca, 3:436-52.
}

${ }^{19}$ Golubovich, Biblioteca, 3:447: 'Item dixit se audivisse ab eodem quod frater Raynerius predictus dicebat, quod tres partes fierent de ordine Minorum, quarum una sola salvaretur, scilicet illa, que in Orientem iret, et propter hoc ipsi fratres Minores venerant et veniebant ad illas partes Orientis.' ${ }^{20}$ On the influence of Joachim of Fiore's apocalyptic ideas, see in particular Marjorie Reeves, The Influence of Prophecy in the Later Middle Ages (Oxford: Clarendon Press, 1969); Reeves, Joachim of Fiore and the Prophetic Future (London: S.P.C.K., 1976); E. Randolph Daniel, 'Heresy and Abbot Joachim of Fiore', in E. Randolph Daniel, Abbot Joachim of Fiore and Joachimism (Farnham: Ashgate, 2011), VIII, 1-19. See also, Nimmo, Reform and Division, 158-76. For the apocalyptic thought of Peter of John Olivi and its influence on the Franciscan dissidents see David Burr, 'The Persecution of Peter Olivi', Transactions of the American Philisophical Society 66 (1976): 1-98. 
Olivi's work, as is made clear by the report sent by the Dominicans to the West. ${ }^{21}$ It may thus not be coincidence that Olivi had predicted in his Apocalypse commentary (and elsewhere) that ' $[u]$ nder pressure from the carnal church in the Latin west, spiritual men will go to the Greeks, Moslems and Jews. There they will find converts albeit at the cost of many martyrs. ${ }^{22}$ It would appear, therefore, that these particular Fraticelli had evolved eschatological ideas of their own concerning the sect's role in the East, influenced possibly by the thought of Olivi, one of the movement's heroes, and the persecution suffered by the sect in the West, which would seem to confirm his apocalyptic vision. ${ }^{23}$ The course that they followed, moreover, mirrored that of Angelo, who attempted to avoid persecution by serving as a missionary in the East (on two occasions) and who, himself was familiar with Olivi's writings. It is possible, thus to infer that the association with the East was already exercising an effect on how the sect saw itself.

Over the next century, the sect appears to have achieved considerable expansion in the Latin dominions of Greece. ${ }^{24}$ The first concrete example of the sect's expansion in Greece

\footnotetext{
${ }^{21}$ Burr, 'The Persecution', 89.

${ }^{22}$ Burr, 'The Persecution', 22.

${ }^{23}$ It is worth noting, however, that the leading expert on Olivi, David Burr, does not find the
} Armenian friars' prophesying about the East as consistent with Olivi's thought. See Burr, 'The Persecution', 89.

${ }^{24}$ As we shall see a number of Fraticelli friaries and communities are mentioned in the surviving sources, but it is impossible to attempt even an estimation of the number of people involved. With the exception of some of the Venetian domains of Greece, most notably Crete, no local archives have survived and thus there are very few sources emanating from the areas in question, other than scraps of correspondence (and especially papal correspondence) preserved in the West. Moreover, though it would appear that some of these Fraticelli communities operated with relative impunity in the Latin dominions of Greece, they were still -as will become clear- the objects of intermittent persecution, which means that some degree of covertness would have been advisable, which possibly limits our 
comes from Philip de Mézières's Life of Saint Peter Thomas: when St Pierre Thomas (130566), papal legate in the East, in charge of assembling a fleet to fight the Turks, found himself in the Venetian colony of Crete in 1359, he discovered heretics in the island's capital, Candia, some of whom were even related to the duke's family, and held trials, eventually burning one of the heretics. ${ }^{25}$ Mézières does not specify what type of heresy was uncovered, but the documents relating to the trial, discovered at the Venetian Archives by Antonio Fabris, have proven conclusively that the heresy in question was in fact Fraticellism. ${ }^{26}$ The heresy had found a foothold among the Venetian nobility of Candia and one of the heresiarchs named Leonardo Gradonigo was even related to the Duke of Candia's wife. Another noble heretic was a youth called Nicoletus Cornario. Eventually all the nobles were reconciled to the Church (contrary to Mézières's assertion) and only a non-noble was executed. Nicoletus Cornario, however, relapsed and abandoned the island and his fiefs in order to join an otherwise unknown Fraticelli community in Thessalonica. ${ }^{27}$ His brother Andreas petitioned Venice to excuse Nicoletus, because of his youth and asked permission to bring him back to the island and restore his fiefs to his family. ${ }^{28}$ It seems that Nicoletus not only returned, but was eventually admitted into the Franciscan order, as indicated by a will composed by a

sources even further. It is therefore necessary to be circumspect in our treatment of the incidents collected in this study, as we cannot tell with confidence how common or rare such occurrences were. ${ }^{25}$ Philip De Mézières, The Life of Saint Peter Thomas, ed. Joachim Smet (Rome: Institutum Carmelitanum, 1954), 87-9.

${ }^{26}$ Antonio Fabris, 'Il Legato Pierre Thomas Inquisitore a Candia: storia di un rogo (1359-1360)', Le Venezie Francescane, nuova serie 6 (1989): 345-63.

${ }^{27}$ Fabris, 'Il Legato', 353 and 361.

${ }^{28}$ The document uncovered by Fabris relates not to the heresy per se but to this dispute over the heretic's property, which his brother was trying to reclaim for the family. 
Nicoletus Cornario in 1362, which includes a postscript of 1372 , noting that the testator was by this time a member of the Franciscan order. ${ }^{29}$ It is, perhaps, worth noting here that the sole known surviving manuscript from the extensive Franciscan library of Candia is a fourteenthcentury codex containing a number of Peter of John Olivi's works relating to the apostolic poverty debate. ${ }^{30}$ These events show that by the mid-fourteenth century the Fraticelli had established communities in the northernmost and southernmost parts of Greece. How important their presence was in these areas is difficult to gauge. Mézières's account implies that the heretics were numerous, and it is clear that noble citizens were involved, but only three individuals are explicitly named in the surviving documents. Nevertheless, it is surely

${ }^{29}$ Sally McKee, ed., Wills of Late Medieval Venetian Crete 1312-1400, 3 vols. (Washington DC: Dumbarton Oaks Research Library, 1998), 1:364-5. The name of the testator and those of his brother and father match the names of the heretic's family. Moreover, one of the witnesses of the will was a certain Leonardo Gradonigo, possibly the same heretic that Nicoletus had had contact with earlier. ${ }^{30}$ Biblioteca universitaria di Padova, cod. 1540. See Victorin Doucet, 'De operibus manuscriptis fr. Petri Ioannis Olivi in bibliotheca univesitatis Patavine asservatis', Archivum Franciscanum Historicum 28 (1935): 156-97 and 408-44. The manuscript is also discussed in Nimmo, Reform and Division, 307, but the citation given there is erroneous. Olivi was considered a saint by the Fraticelli and it has recently been suggested that the Cretan Franciscans may have confiscated this manuscript from a suppressed community of Fraticelli. Given, however, that a former Fraticello had been accepted into the Candiote friary, and given the number of Olivi's works that the library possessed, one might consider the possibility that the Candiote friars were themselves interested in these matters. For the suggestion that the codex had been confiscated, see Sylvain Piron, 'Les premières leçons d'Olivi sur les restitutions', Oliviana 4 (2012): 1, http://oliviana.revues.org/527 (accessed July 26, 2017). For the holdings of the Franciscan library of Candia more generally, see Giorgio Hofmann, 'La biblioteca scientifica del monastero di San Francesco a Candia nel medio evo', Orientalia Christiana Periodica 8 (1942): 315-61. 
significant that decisive action was only taken against them once Pierre Thomas, an outsider, found himself on the island, so Mézières's assertion that the heretics were protected by the local authorities seems plausible. The existence of a reasonably small -and therefore tightly interconnected-Venetian elite in this colonial setting would have surely encouraged some degree of toleration among the Venetian nobles. We can see glimpses of this toleration in the documents discovered by Fabris in the Venetian Archives: one of the nobles who had benefitted from Nicoletus's abandonment of his fiefs, described Nicoletus's motivation thus: 'having put aside worldly things, [he] dedicated himself entirely to the service of God, [and] chose to abandon his homeland and family and to wander for this intention in the habit of poverty and thus he left Crete, solely for the purpose of devotion and pious religion.' ${ }^{31}$ True, this particular deponent had good (financial) reasons to present Nicoletus's decision in the best possible light, but it is exactly these kinds of bonds in a small, tightly knit community that could have encouraged the toleration of dissidence. If Nicoletus was indeed rehabilitated into Veneto-Cretan society and even allowed into the Franciscan order, then we see also the kind of laxity that may have facilitated the sect's proliferation in the Greco-Latin East: such leniency would have been almost unimaginable for a relapsed heretic in the West.

Direct information about the heretics in Greece in the subsequent decades is scarce, but they clearly remained a problem and proliferated in the fifteenth century. The biographer of St Giovanni Capistrano (1385-1456) tells us that the saint managed to burn 36 of their loca

\footnotetext{
31 'postpositis rebus temporalibus, se totum divino dedicavit obsequio, eligit patriam et cognationem reliquere ac pro proposito peregrinari in habitu paupertatis et sic exivit de Creta, sola occasione devotionis et pie religionis;' Fabris, 'Il Legato', 362.
} 
around Ancona in the fifteenth century and forced many of the heretics to flee to Greece. ${ }^{32}$ Their move to Greece was well-known in the West and the popes appointed Inquisitors to deal with the heretics in the Greek lands on at least two occasions, in 1429 and $1451 .{ }^{33}$ On both occasions, the sect was said to be concentrated in Athens and by 1451 the sect's 'pope' was believed to reside there as well. Again, though these letters present the Fraticelli as a major threat to the Church in Athens, it is not possible to know how many the 'many heretics' were. As we shall soon see, however, the popes were right to fear that the heretics of Athens would be lure others to their faith, for a few years later they were active as missionaries.

An interesting reference to the Fraticelli of Greece during this period comes from a letter that the Latin bishop of Argos had sent to the Venetian senate in 1437. Amongst the problems facing his church, he said, was the sect of the Fraticelli, who subverted his territory with their major errors that they have learned from the Greek rite. ${ }^{34}$ Evidently, the bishop was

\footnotetext{
${ }^{32}$ Johannes Bollandus et al., eds., Acta sanctorum quotquot toto orbe coluntur, vel a catholicis scriptoribus celebrantur... Oct. X (Paris: Victor Palmé, 1869), 58:448.

${ }^{33}$ Cesare Cenci, ed., Supplementum ad Bullarium Franciscanum, 2 vols. (Grottaferrata: Editiones Collegii S. Bonaventurae ad Claras Aquas, 2002), 1:343; and Livario Oliger, 'Documenta inedita ad historiam Fraticellorum spectantia', Archivum Franciscanum Historicum 6 (1913): 515-30, here 52930.
}

${ }^{34}$ The letter itself does not survive, but the Venetian response, reproducing one by one the points of

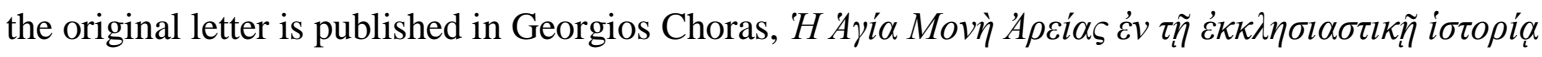

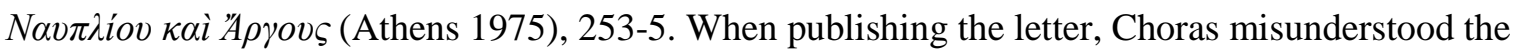
point about the Fraticelli, and took it to be a reference to rebellious Greek monks, but in fact there can be no doubt that this is a reference to Fraticelli heretics: '... sunt etiam sibi vicini quidam heretici, qui dicuntur fraticelli, qui libenter subverterent patriam illam ad majores errores quos habeant ex greco ritu...' 
assuming that the heresy of the Fraticelli was somehow connected to Greek doctrine. Can we imagine that the bishop was entirely ignorant of the sect's history even though it had sprung out of the Apostolic poverty debate, one of the major controversies to preoccupy the Latin Church in the fourteenth century, and instead assumed that it had been born out of Greek influence? That seems unlikely, but what is evident is that once again the proponents of apostolic poverty were associated by their enemies with the Greek Church. As we have seen, the Spiritual Angelo Clareno had also been accused of preferring the Greek Church to the Roman one and, even though he denied it, he had for a period maintained close relations with a group of Greek monks.

That the persecuted heretics fled to the Latin dominions of Greece should not come as a great surprise under the circumstances. In the chaotic fifteenth century one can imagine all sorts of outlaws and adventurers making their way to these lands, where political authority was weak and thus persecution remained ineffective. ${ }^{35}$ What is more interesting is that traffic of heretics and heretical ideas between the West and Greece seems to have been a two-way process. In 1466-67, a trial was held in Rome of a group of Fraticelli who were apprehended

\footnotetext{
${ }^{35}$ The late fourteenth and early fifteenth centuries saw the expansion of the Turks into Greece at the expense of the Latin states and warfare between Albanians, Navarrese, Catalans, Angevins, Venetians and the Acciaiuoli over what remained of the increasingly fragile Latin lands. By the end of the fifteenth century, the Ottomans had almost completed their conquest of mainland Greece, with only small enclaves of Latin power remaining in the Peloponnese. For a brief summary of these events, see Peter Lock, The Franks in the Aegean (London and New York: Longman, 1995), 108-34. For a more detailed account of the turbulent history of Athens -apparently the heretics' stronghold-in that period, see Kenneth M. Setton, 'The Catalans and Florentines in Greece, 1380-1462', in Kenneth M. Setton and Harry W. Hazard, eds., A History of the Crusades, 6 vols. (Madison: The University of Wisconsin Press, 1975), 3: 225-77.
} 
whilst making their annual pilgrimage to the Portiuncula. This trial, whose records have partially survived, is also considered to be the final appearance of the Fraticelli in our sources, after which the sect supposedly died out. The trial records have preserved some important information about the heretics' presence and activity in Greece. ${ }^{36}$

One of the heresiarchs was a man who went by the name of Bernard of Bergamo. According to his testimony, he had joined the sect around the late 1450s or early 1460s in Greece, where there existed four heretical convents, named as St Mary of Athens, Walta, St Francis of Thebes and St George in the Castle of Syccaminon (near Oropos). Later, he returned to Italy as a missionary for the sect, setting up communities of Fraticelli in Latium and around Ancona. So we have here clear evidence that, having established themselves in Greece, where they had fled from persecution, the heretics then undertook the propagation of the sect back in its original homeland, Italy, and in particular the territory of Ancona.

Moreover, it is possible to see that the flourishing of the sect in the territories of central Greece was anything but accidental. It appears that the heretics had close connections with the ruling Florentine aristocracy of Athens and its hinterland. During the trial, the heretic Bernard of Bergamo named as one of his associates a certain Luigi Pitti. ${ }^{37}$ This Luigi Pitti was the son of Nerozzo Pitti and Laudamia Acciaiuoli, Lady of Syccamino and niece of Antonio Acciaiuoli, the duke of Athens. ${ }^{38}$ In other words one of the heretics was the great-

\footnotetext{
${ }^{36}$ Ehrle, ed., 'Die Spiritualen', 110-34.

${ }^{37}$ Ehrle, ed., 'Die Spiritualen', 116.

${ }^{38}$ See also John N. Stephens, 'Heresy in Medieval and Renaissance Florence', Past and Present 54 (1972): 25-60. The heretic Luigi Pitti was also related to the famous Florentine diarist Buonaccorso Pitti. See Buonaccorso Pitti, Cronica di Buonaccorso Pitti, ed. Alberto Bacchi della Lega (Bologna: Romagnoli dall'Acqua, 1905), 239-40. A letter by Luigi Pitti to the Florentine authorities has survived
} 
nephew of the duke of Athens and heir to the Castle of Syccaminon. As we have seen already, a heretical convent was operating openly within this castle. ${ }^{39}$

Florence was a well-known hot-spot for this heresy and it is interesting to speculate on whether the Acciaiuoli were themselves directly involved with the sect. The Pitti family, who, as we saw, intermarried with the Acciaiuoli and were one of the most prominent Florentine families in their own right, certainly had connections with the sect well before the time of Luigi Pitti. We know of these, incidentally, through the writings of a Dominican friar, Manfred of Vercelli, who wrote a treatise against the Fraticelli in Florence in $1425 .{ }^{40}$ Manfred begins his treatise by relating that when he went to Florence and found out how prominent the heresy of the Fraticelli was there, he decided to talk to the heretics in person and convince them of their errors. Understandably, most of the heretics shunned Manfred, fearing that he intended to arrest and burn them, but one citizen agreed to debate with him. This heretic was named Cambinus Pitti. ${ }^{41}$

Manfred of Vercelli offers one more important piece of information, which has thus far been overlooked: whilst attempting to engage with the Fraticelli of Florence, he convinced

and is published in William Miller, Essays on the Latin Orient (Cambridge: Cambridge University Press, 1921), 160-1.

${ }^{39}$ Syccaminon was a castle in Attica, near Oropos. It had belonged to the Templars in the first years after the Frankish conquest, before passing into the possession of the Knights Hospitaller. In the fifteenth century it was owned by the Florentines. See Kristian Molin, Unknown Crusader Castles (New York and London: Hambledon and London 2001), 264 and 267.

${ }^{40}$ Raymond Creytens, ed., 'Manfred de Verceil O. P. et son traité contre les Fraticelles', Archivum Fratrum Praedicatorum 11 (1941): 171-208.

${ }^{41}$ Creytens, 'Manfred de Verceil', 191. 
them to send him their books, so that he might be informed of their faith. These books (which he claims to have read) were written in the vulgar tongue (i.e. the Italian vernacular) but also -he says- in Greek! ${ }^{42}$ How should we explain this intriguing reference to Greek heretical manuscripts, circulating in Florence? It is possible, of course, that Manfred was simply lying, in order to further discredit his opponents, by linking them to the Greeks. If that is indeed the case, then he was following the exact same strategy that Angelo Clareno's denouncers employed when they accused him of preferring the Greek Church to the Latin one, and that the bishop of Argos would employ a few years later, by suggesting that the Fraticelli learned their errors from the Greeks. But is it possible that there were in fact Greek heretical tracts circulating in Florence already forty years before Bernard of Bergamo was sent to reinvigorate the sect in Italy? It seems intuitively unlikely: even assuming that heretical treatises had been produced in Greek by the Florentine expatriates of Greece, it is improbable that they would be circulating in Greek (rather than in translation) back in Florence, unless Manfred's correspondents were themselves members of the Greco-Florentine community, travelling back and forth from Greece to Italy, like Bernard of Bergamo apparently did in the 1460s. Another, perhaps more likely, explanation is that the texts Manfred was sent were excerpts of orthodox Greek patristic texts, which in the eyes of the heretics, might seem to affirm the Greek Church's agreement with their own opinions. Such patristic texts could have circulated in the Humanist circles of Florence quite independently of any heretical connection. Finding out what Greek patristic texts were available in Florence in the first two decades of the fifteenth century is not easy, but one thing seems clear: although the influx of classical Greek texts had started ever since Manuel Chrysoloras had come to Florence in 1397, Greek patristic texts were much scarcer until the time of the Council of Ferrara and

\footnotetext{
${ }^{42}$ Creytens, 'Manfred de Verceil', 191.
} 
Florence in the $1430 \mathrm{~s} .{ }^{43}$ It may therefore not be coincidental that amongst the very first Greek patristic texts that can be safely located in Florence before 1420 are the writings of John Climacus and Basil of Caesaria; ${ }^{44}$ the very same texts whose ascetic spirit had also inspired Angelo Clareno. ${ }^{45}$

In concluding, how can we assess the effects of the Fraticelli presence in Greece? The zealots of Franciscan poverty were drawn to the East from early on due to the absence of

\footnotetext{
${ }^{43}$ For the rediscovery of the Greek fathers, see Sebastiano Gentile, 'Umanesimo fiorentino e riscoperta dei Padri', in Umanesimo e Padri della Chiesa: manoscritti e incunaboli di testi patristici
} da Francesco Petrarca al primo Cinqucento, ed. Sebastiano Gentile (Rome: Rose, 1997), 45-61. ${ }^{44}$ These works were acquired and translated into Latin by Ambrogio Traversari. In acquiring John Climacus, Traversari had in fact stated his intention to produce a translation that would supersede an earlier translation which he considered to be inept. This was probably a reference to Clareno's translation. See Gentile, 'Umanesimo fiorentino e riscoperta dei Padri', 47.

${ }^{45}$ It has to be noted here that a number of Fraticelli treatises survive, most of which are not evidently influenced by Greek writings. Both the Fraticelli apologists and their opponents rely predominantly on Scriptural references, the Latin Fathers, papal and conciliar decrees and canon law to make their case. Of the Greek Fathers, only John Chrysostom is cited fairly regularly, both by the Fraticelli and by their opponents. One Fraticelli text, however, written in Narni in the mid-fourteenth century, repeatedly cites St Basil in support of the absolute poverty of Crist and the Apostles. See Livario Oliger, ed., 'Documenta inedita ad historiam fraticellorum spectantia', Archivum Franciscanum Historicum 6 (1913): 290, 515 and 517. Moreover, the dependence of some of the Fraticelli on Basil for their arguments in defence of poverty seems to have been known to their opponents: in his antiheretical treatise of 1381, Friar Andrea Richi argued that Chrysostom, Augustine and Bede were all united in their opinion concerning the house provision of the Apostles, but that Basil differed: Oliger, 'Documenta inedita' 3 (1910): 276. For other examples of the use of John Chrysostom, see Oliger, 'Documenta inedita' 4 (1911): 708; 6 (1913): 288; and Tocco, Studii Francescani, 513. 
institutionalised persecution. ${ }^{46}$ Though the migration to Greece was brought about by necessity, the memory of the migration, preserved by the writings of Clareno, appears to have played an important role in the collective consciousness of the Spirituals and their successors, the Fraticelli, as well as that of their opponents. ${ }^{47}$ Central in this was Clareno's miraculous acquisition of the Greek language. The story was of course important because, in the eyes of his disciples, it proved Angelo’s sainthood. Accordingly, it was widely reported and eventually accepted even by the adversaries of absolute poverty. The Vallombrosan monk Giovanni dalle Celle, for example, writing against the Fraticelli in the late fourteenth century conceded that such a miracle had indeed taken place. ${ }^{48}$ At least one other story circulated, which assigned importance to the Spirituals' knowledge of Greek. It was said that whilst in Greece, Angelo or one of his followers discovered in a Greek patristic text, that the name of the Antichrist was Benedict and therefore the Antichrist could be identified as Pope Boniface

\footnotetext{
${ }^{46}$ Though as is obvious from the examples of Angelo Clareno and the heretics of Candia, even there the fugitives were not entirely safe from the suppression mechanisms of the Latin Church.

${ }^{47}$ The writings of Angelo Clareno remained among the favourite readings of the Spirituals and the Fraticelli. One of the heretics who wrote a defence of the sect mentioned the friars' escape to Greece and Crete twice. He clearly knew of the journey to Greece through Angelo's own writings, which he cites, but Angelo does not mention Crete and it is unknown how he got this information. See Tocco, Studii Francescani, 518 and 520.

${ }^{48}$ Giovanni dalle Celle conceded as much in a letter written against the Fraticelli, published in Pia Civaldi, Il Beato Giovanni dalle Celle, Atti della Reale Accademia dei Lincei 12 (Rome: Academia dei Lincei, 1906) 354-477, here 469. For more evidence of how widespread the belief in the miracle was, see Oliger's introduction to Angelo Clareno, Expositio Regulae Fratrum Minorum, ed. Livario Oliger (Quarrachi: Typis Collegii S. Bonaventurae, 1912), xxxv-xxxviii.
} 
VIII, who was born Benedict Gaetano. ${ }^{49}$ Much of this was consistent with the prophesying of Peter of John Olivi -venerated as a saint by the sect- who had predicted that, during the time of the Antichrists, the spiritual men would be driven to the East by the persecution of the carnal church; there they would evangelize the Greeks, who would, in turn, show the Latin Church its errors. ${ }^{50}$

In the following centuries, Fraticellism grew in Greece, both through fugitives arriving from the West as well as through converts resident in Greek lands. Throughout the period of Latin rule (1204-1797) the Latins of Greece remained in touch with their western motherlands, and continued to be influenced by the cultural and religious currents of the West. The proliferation of heretical ideas was just another aspect of this process. What is more intriguing is that, from the fifteenth century onwards, the heretics of Greece took a leading role in reinvigorating the movement in the West. We have seen, for example, that Bernard of Bergamo managed to set up several heretical communities in Italy before he was arrested by the Inquisition. The Greek texts mentioned by Manfred of Vercelli, even earlier than this, may also suggest the movement of heretics from Greece westwards before 1425 .

\footnotetext{
${ }^{49}$ Ubertino Da Casale, Arbor Vitae Crucifixae Jesu Christi (Venice: Andreas de Bonetis, 1485), 232r. The excerpt is also published in the introduction of Clareno, Expositio Regulae Fratrum Minorum, xxxix; and von Auw, Angelo Clareno, 60. According to Ubertino the story was related to him by the man who made the discovery, who was fluent in Greek, thus possibly Angelo Clareno himself. Along with other Spirituals he was said to have taken refuge amongst the Greeks. The text which supposedly gave him this insight was a treatise of St Justin the Martyr (†c.130 AD) on the book of Revelation. No such treatise by St Justin has survived.

${ }^{50}$ Burr, 'The Persecution', 22.
} 
If these books were in fact Greek patristic texts, rather than heretical writings, as seems more likely, then we can see that ever since their early involvement with Greece the proponents of absolute poverty followed a consistent strategy: they looked to the Greek tradition to prop up their own position in their disputes with the Latin Church. Angelo Clareno started the trend, by translating John Climacus and Basil's Rule, works that would appear to defend his own ascetic ideals which had brought him into conflict with his order and the papacy. At the same time, he (or one of his disciples) sought to confirm the sect's eschatological ideas by invoking the Greek fathers - on this occasion an apocryphal work by St Justin the Martyr. Apparently, eschatology even took on a particularly eastern focus, amongst the sect's representatives in the East, as is indicated by brother Raynerius's assertion that only the Franciscans who went to the East would be saved. The Fraticelli of Argos in the 1430s must also have continued to rely on Greek authority; that is how we have to interpret the bishop's claim that their errors were connected to the Greek rite. So if the elusive Greek books circulating in Florence were indeed Greek patristic texts, the Fraticelli were once again engaging in the time-honoured tradition of invoking the authority of the Eastern Church to resolve their own disputes with the papacy. Accordingly, both Angelo Clareno and the Fraticelli were at times accused of making common cause with the Greek Church. ${ }^{51}$ These accusations may also have been attempts to identify these dissidents as followers of Olivi, which, by the mid-fourteenth century would have been proof of heresy ipso facto, since Olivi's Apocalypse commentary was censured as heretical in $1326 .{ }^{52}$ That said, their

\footnotetext{
${ }^{51}$ As mentioned above, Angelo vigorously denied those accusations. The Fraticelli, moreover, despite sometimes relying on the Greek Fathers to support their positions, routinely referred to the Greeks as schismatics and heretics in their writings. See for example Oliger, 'Documenta inedita', Archivum Franciscanum Historicum 4 (1911): 699; 5 (1912): 77; 6 (1913): 523.

${ }^{52}$ Burr, 'The Persecution', 80-90.
} 
opponents were not above using the same methods in their own disputes with the papacy. As we have seen, the mainstream Franciscan bishop of Caffa defended Christ's poverty by asserting that it was held as an article of faith by the Greek Church. Nor did this trend subside with the end of the Middle Ages and the extinction of the Franciscan dissidents. A similar effort was made by heretical Hussites in 1451, who approached the Greek Church seeking confirmation of their views. ${ }^{53}$ This process culminated much later, when the Lutheran Reformers of the sixteenth century submitted their positions to Patriarch Jeremias II, in an attempt to secure the testimony of the Orthodox against Roman doctrine..$^{54}$

It is still impossible to quantify the presence of the heresy in the Latin states of Greece with any precision: we cannot know how many communities or convents existed, nor how many brothers these communities housed. More importantly, we cannot really assess the effect of the sect on the societies of the Greco-Latin East. But our examples have shown that, as was the case in other territories where the sect established a presence, the zealots of poverty were sometimes successful in attracting support among the ruling classes of the local societies. The existence of four convents in central Greece in the middle of the fifteenth

\footnotetext{
${ }^{53}$ Milada Paulová, 'L’Empire Byzantine et les Tchèques avant la chute de Constantinople', Byzantinoslavica 14 (1953): 158-225, here 203-24; and Steven Runciman, The Great Church in Captivity: a Study of the Patriarchate of Constantinople from the Eve of the Turkish Conquest to the Greek War of Independence (Cambridge: Cambridge University Press, 1968), 238.

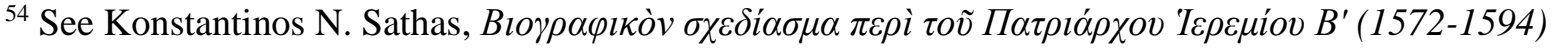
(Athens: A. Ktena and S. Oikonomou, 1870), $\imath \eta^{\prime}-\mu \beta^{\prime}, \mu \eta^{\prime}-\nu \delta^{\prime}$; Martinus Crusius, Turcograeciae libri octo (Basle: Per Leonardum Ostenium, Sebastiani Henricpetri impensa, 1584; repr. Modena, 1972),

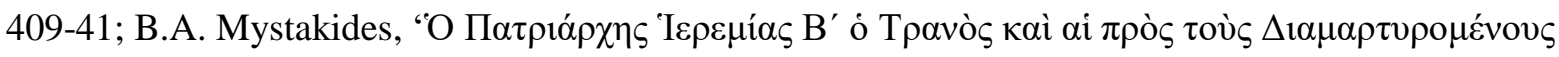

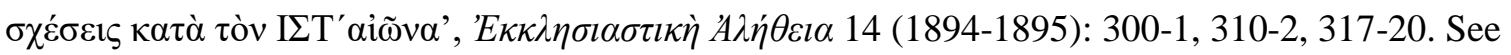
also, Runciman, The Great Church in Captivity, 238-59, here 247-59.
} 
century, a period of rapid decline and collapse for the Latin states, must also be counted as a significant achievement for the sect. The concern of the Church, therefore, that saw the expansion of the sect in Greece as a serious threat, may not have been an overreaction. Most importantly, however, what our analysis has shown is that, though the Apostolic poverty controversy was an entirely Latin Christian affair, the migration of zealots to the East, starting with Angelo Clareno, embroiled the Greek tradition into the debate, alternately to provide support for the zealots' position and to prove their heterodoxy.

In closing, it is worth noting that the prophesy of Raynerius of Florence, the Franciscan Fraticello of Tabris, who had predicted in the 1330s that only the members of the order that migrated to the East would be saved, was, in certain ways, fulfilled: as we have seen, the last ever trial of the Fraticelli was held in Rome between 1466 and 1467; after this, the sect is thought to have finally disappeared. Two hitherto disregarded references, however, prove that the sect survived for at least a few more years in the East. In 1470 following the capture of Negroponte by the Turks, Giovan Maria Angiolello, one of the city's defenders was dragged to Istanbul as a slave by his Ottoman captors. Passing through Ottoman Athens (which had already capitulated to the Turks in 1456), he wrote in his journal:

In this place, named Satines [i.e. Athens], there are many old buildings and there is a monastery of the brothers of the order of Opinion, who do not give obedience to our Pope; and most of them are Florentines, they celebrate office in Italian and their speech and 
writing is Italian; and they have a most beautiful place, with a great entrance and thus they live off their own means. ${ }^{55}$

Four years later, a scribe updating the chronicle of Andrew of Regensburg with recent developments in the East, and lamenting the fall of Negroponte to the Ottomans, wrote: 'not far [from the town of Negroponte] there exists a monastery of the Order of St Francis, whose brothers are called Opiniani, but nevertheless they are Christian' ${ }^{56}$ There can be no doubt that these opiniani were none others than the Fraticelli of opinion, who, driven out of the West, had now found their final refuge among the Turks.

\footnotetext{
${ }^{55}$ Giovan Maria Angiolello, Viaggio di Negroponte, ed. Cristina Bazzolo (Vicenza: Pozza, 1982), 14 : 'In questo luogo, nomalto Satines, vi sono assai antiche fabriche e vi è anco un monasterio di frati dell' ordine della Opinione, i quelli non danno obedienza al Ponteficato nostro; e sono la maggior parte fiorentini, officiano alla italiana, ed il parlar e legger suo è italiano, ed hano un bellissimo luogo, con grande entrata, sicché vivono del suo.'

${ }^{56}$ The excerpt is published in Nicolae Iorga, ed., Notes et extraits pour servir à l'histoire des croisades au XVe siècle, 6 vols. (Bucharest: Édition de l'Académie Roumaine, 1915), 4:346: 'De hinc non alonge situm est monasterium quoddam ordinis S. Francisci, cujus fratres appellantur Oppinianj, tamen Christiani sunt.'
} 